\title{
A COMPARATIVE STUDY ON INDONESIAN AND MALAYSIAN CONSUMERS' PERCEPTION AND PREFERENCE TOWARDS HANDPHONES FROM CHINA, SOUTH KOREA, AMERICA, AND EUROPE
}

\author{
Silvia Dewi Sagita Andik*)1, Jono M Munandar*), and Mukhamad Najib*) \\ *) Department of Management, Faculty of Economics and Management, Bogor Agriculture University \\ Jl. Agatis, Campus IPB Dramaga, Bogor 16680
}

\begin{abstract}
Most handphones in Indonesia and Malaysia are imported from other countries such as from America, Europe, China, and South Korea. The enhancement of global brands has reduced local brand preferences. This research aims to clarify the consumers' perception towards brands of handphones in Indonesia and Malaysia by conducting comparative studies in both countries and examining the effects of product attributes and brand image on brand preference. Questionnaire surveys were conducted to 200 respondents from Indonesia \& Malaysia. The data were analyzed by the descriptive analysis, Semantic Differential Scale Analysis, ANOVA test, and Structural Equation Modelling Partial Least Square (SEM-PLS). It has been clarified that there are differences in preferences between consumers in Indonesia and Malaysia in terms of product attributes. Thus, the results of this research give benefits to the market expansion and product development in both countries.
\end{abstract}

Keywords: brand preference, consumers' perception, country of origin, brand, structural equation modeling

Abstrak: Sebagian besar handphone di Indonesia dan Malaysia diimpor dari negara lain. Sebagian besar diimpor dari Amerika, Eropa, China, dan Korea Selatan. Peningkatan merek global menurunkan preferensi merek lokal. Penelitian ini bertujuan mengklarifikasi persepsi konsumen terhadap merek handphone di Indonesia dan Malaysia dengan melakukan studi komparatif di kedua negara dan menganalisis pengaruh atribut praduk dan citra merek terhadap preferensi merek. Survei menggunakan kuesioner telah dilakukan kepada 200 responden di indonesia \& Malaysia. Data dianalisis menggunakan analisis deskriptif, Skala Diferensial Semantik, uji ANOVA dan Structural Equation Modelling Partial Least Square (SEM-PLS). Telah diklarifikasi bahwa ada perbedaan terhadap preferensi ponsel antara konsumen di Indonesia dan Malaysia dalam hal atribut produk. Dengan demikian, hasil penelitian ini memberi manfaat bagi perluasan pasar dan pengembangan produk di kedua negara.

Kata kunci: preferensi merek, persepsi konsumen, country of origin, merek, structural equation modeling

\footnotetext{
${ }^{1}$ Corresponding author:

Email: silviadewisagitaandik@gmail.com
} 


\section{INTRODUCTION}

Imported handphones have dominated the Indonesian and Malaysian markets. There are various brands of handphones from different countries (such as America, China, Europe, and South Korea). Based on Top Brand Index (2017), it is reported that handphones from South Korea, America, and Europe are still priority in Indonesian market. In addition, handphones from China also dominate the Indonesian market and Malaysian market. The increase in Chinese handphones shows a change of preference for Chinese brand goods, especially handphones.

Table 1 shows that the market share of handphones from China began to increase by $8 \%$ while global and local handphones began to decline. The global is the one that has a name in the international market, such as handphones from America, South Korea, and Europe. An increase in China's market share shows that Chinese handphones haveincreased. Besides Indonesia, Malaysia is also one of the potential countries for the market in Southeast Asia. International Data Corporation (IDC) Asia Pacific (2017) also noted the number of imported handphones increased by $35 \%$ in Malaysia.

Table 1. Market share of handphones in Indonesia

\begin{tabular}{ccc}
\hline $\begin{array}{c}\text { Country of } \\
\text { Origin }\end{array}$ & $\begin{array}{c}2016 \\
\text { Market Share }\end{array}$ & $\begin{array}{c}2017 \\
\text { Market Share }\end{array}$ \\
\hline China & $23 \%$ & $31 \%$ \\
Global & $51 \%$ & $47 \%$ \\
Local & $20 \%$ & $17 \%$ \\
Others & $6 \%$ & $5 \%$ \\
\hline
\end{tabular}

Source: IDC Asia/Pacific Quarterly Mobile Tracker 2017Q1

The enhancement of global brands shows that the telecommunication industry is highly competitive and dynamic (Alamro \& Rowli, 2011). Circulated global brands in the market make a decrease in local brand preferences (Schultz et al. 2014). If the local telecommunication industry wants to compete in the market, then the local telecommunication industry should focus on a brand preference. A brand preference is the consumer's preference for a particular brand (Hellier et al. 2003). Brand preferences are influenced by brand image. Brand image is a symbol of brand quality (Khan M, 2016).

Research conducted by Andhika et al. (2016) states that a brand image has an influence on a brand selection. One of the brand image elements is the product attribute.
Product attributes also need to be noticed by marketers (Roseli et al. 2016; Lee and Nguyen, 2017). Product attributes include a product quality, a feature quality, a product price, and a country of origin. The higher the consumer demand, the more handphones offered at various feature qualities (Khan M, 2016). In addition to the feature quality, the country of origin is also the main focus of consumers in evaluating brands. The country of origin also affects the consumer brand preference for automobile and television products (Essoussi et al. 2011). Chinese consumers and Russian consumers are more concerned with the country of origin when buying luxury goods (Godey et al. 2012). Handphones coming from different countries create their own perceptions for consumers.

A consumer perception is a process by which consumers choose, organize, and translate information inputs to create meaningful world images (Kotler, 2002). There are differences in perception towards the brand origin, such as the perception of Chinese brands. Laforet and Chen (2012) explained that Chinese brands have poor quality, especially in the category of luxury goods. This is contrary to the opinion of Nadia and Rashid (2016) which states that Malaysian consumers judge the Chinese is considered to give a positive perception. In addition to the perception of country origin, consumer perceptions are also related to price attribute. It becomes an important aspect in purchase intention of handphone. Based on the research conducted by Khan M (2016), it is explained that young consumers tend to be less sensitive to the price when they want to express their self-image in the social environment. Yee et al. (2013) also states that the brand shows one's lifestyle and social status in its peer group environment.

The enhancement number of imported handphones in Indonesia and Malaysia indicates the two countries are very potential markets for handphone products. In addition, marketers offer a diversity of feature qualities. It makes the increasing number of various handphones which are offered by marketers. Young consumers mostly use their activities by using handphones (Agustin et al. 2011). Based on demographic characteristics, the two countries (Indonesia and Malaysia) have different cultures and lifestyles. Indonesia has more than 50 ethnic groups spreading across the country, while Malaysia has three dominant ethnic groups. This shows that Indonesian consumers are more heterogeneous than Malaysian consumers. Several previous literary studies examined the effect of product attributes and brand image 
on handphone purchase intention in both countries, but not many have focused on the brand preference. Alamro \& Rowly (2011) stated that building a brand preference is very important to compete in the world of telecommunication industry, especially handphones. Assessing perceptions of handphone attributes have to be considered in building brand preferences. This is a new point in evaluating consumer perceptions of handphones.

Based on the point of view, the objectives of this study are (1) to clarify the different perceptions of handphones from China, South Korea, America and Europe to consumers in Indonesia and Malaysia (2) to examine the effect of product attributes and brand images on the brand preference among consumers in Indonesia and Malaysia.

The scopes of this research are as follows: A comparative study of Indonesian and Malaysian consumers. The respondents selected were students. The reasons for the selection are: students are a huge market; students recognize issues related to product brands (Alamro and Rowly, 2011); In addition, Acker and Keller (1990) stated that the students are appropriate respondents for brand research. Product evaluated is handphone from four countries (America, South Korea, China, and Europe). Product attributes include quality, price, and country of origin.

\section{METHODS}

This research was conducted in Indonesia and Malaysia. Time for collecting secondary and primary data began in April-June 2017. The primary data were taken through interview using questionnaire instrument. The secondary data were taken from the Ministry of Trade of the Republic of Indonesia and the literature related to the present research, such as books, journals, and reports. The sampling technique used in this research was convenience sampling (Salkind, 2010). The total sample size was 200 (100 Indonesian students and 100 Malaysian students). The number of samples was taken based on the Roscoe formula (1975). Data were processed and analyzed using descriptive, cross tab, semantic differential scale, ANOVA, and Structural Equation Modeling (SEM-PLS).
Semantic differential scale can be used to analyze Indonesian consumer perception and Malaysian consumer perception toward the attribute of handphone. The semantic differential scale has a range of scale between 1 and 10. Anova analysis is used to test the difference of each attribute on the four handphones (from China, South Korea, America, and Europe). According to Ghozali (2008), Structural Equation Modeling (SEM) is used to examine the effects of product attributes and brand image on brand preferences. The measurement of latent variables in the initial model consists of 17 indicators. The results of the study became a recommendation for the telecommunication industry.

A brand preference is the key factor in building a brand (Alamro \& Rowly, 2011). There are several factors that affect brand preferences. Lee \& Nguyen (2017) stated that the symbolic attributes of fashion products affect the brand preference. Product attributes include quality, price, and country of origin. Perceptions of product attributes are a major consideration in brand preferences (Bass \& Talarzyk, 1972). Quality influences the level of consumer preference for a particular brand (Hellier et al. 2003; Duarte \& Raposo, 2010; Alamro \& Rowly, 2011; Renganathan et al. 2016). A good quality will increase brand preference. In addition, prices also affect brand preferences (Alamro \& Rowly, 2011; Ebrahim et al. 2016). Country of origin is a major consideration for consumers in evaluating brands (Alamro \& Rowly, 2011; Essousi et al. 2011; Laforet \& Chen, 2012; Godey et al. 2012; Lee \& Nguyen, 2017). Product attributes are antecedents of the brand image. A brand image affects consumer preferences for a particular brand (Duarte et al. 2010; Saaksjarvie \& Samie, 2011). The brand image of the product will increase if perceptions of product attributes are considered good. A country of origin is one of the product attributes is analyzed in this research. The country of origin affects brand images (Kim et al. 2015). Price and quality also affect the brand image (Alamro \& Rowly, 2011). Based on the literature review, the hypotheses are developed in Figure 2.

Hypotheses developed from literature review are as follows:

H1a : Price affects brand preference

$\mathrm{H} 1 \mathrm{~b}$ : Price affects brand image

$\mathrm{H} 2 \mathrm{a}$ : Quality affects brand preference

$\mathrm{H} 2 \mathrm{~b}$ : Quality affects brand image

H3a : Country of origin affects brand preference

$\mathrm{H} 3 \mathrm{~b}$ : Country of origin affects brand image

H4 : Brand image affects brand preference 

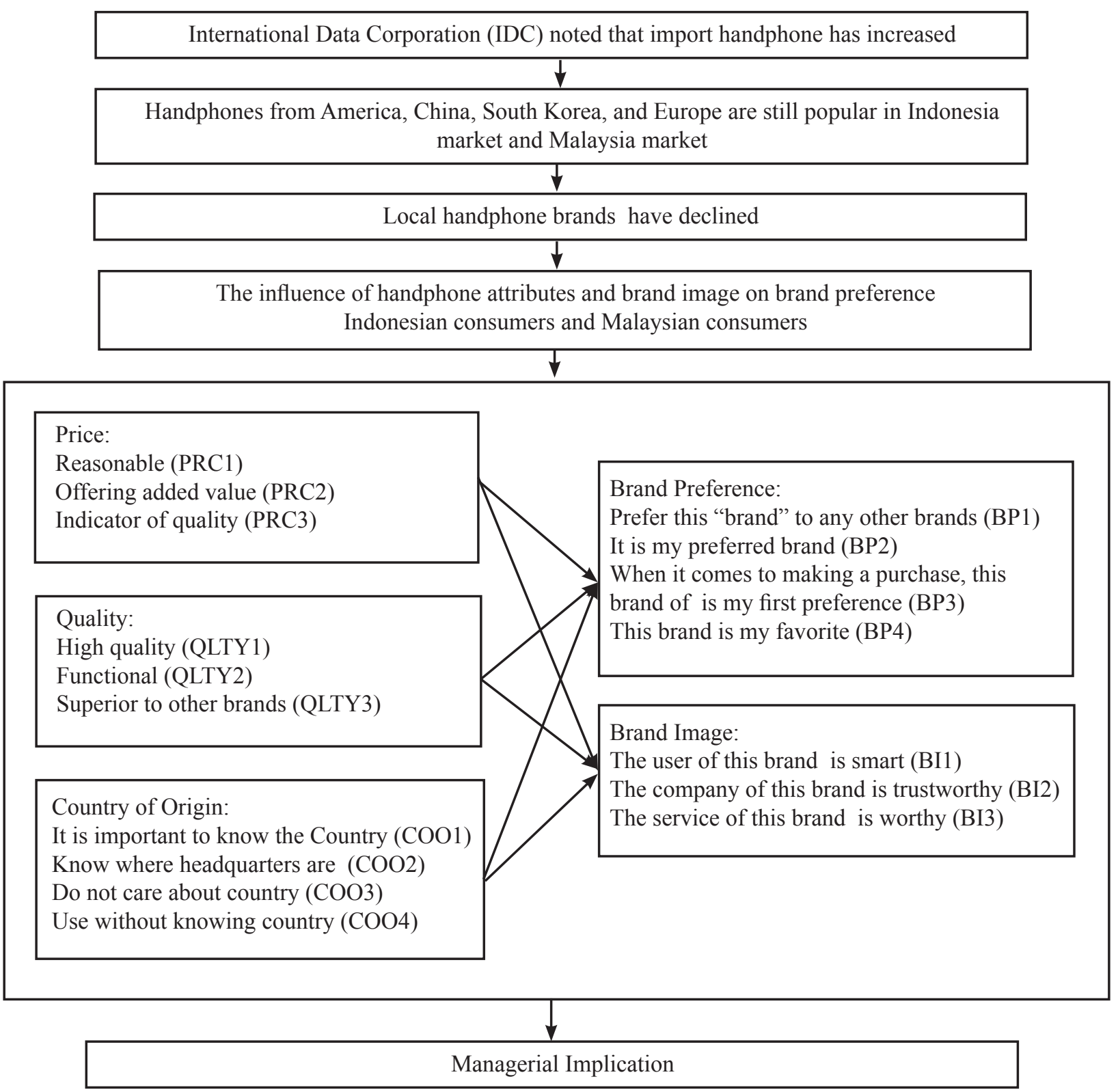

Figure 1. Research framework

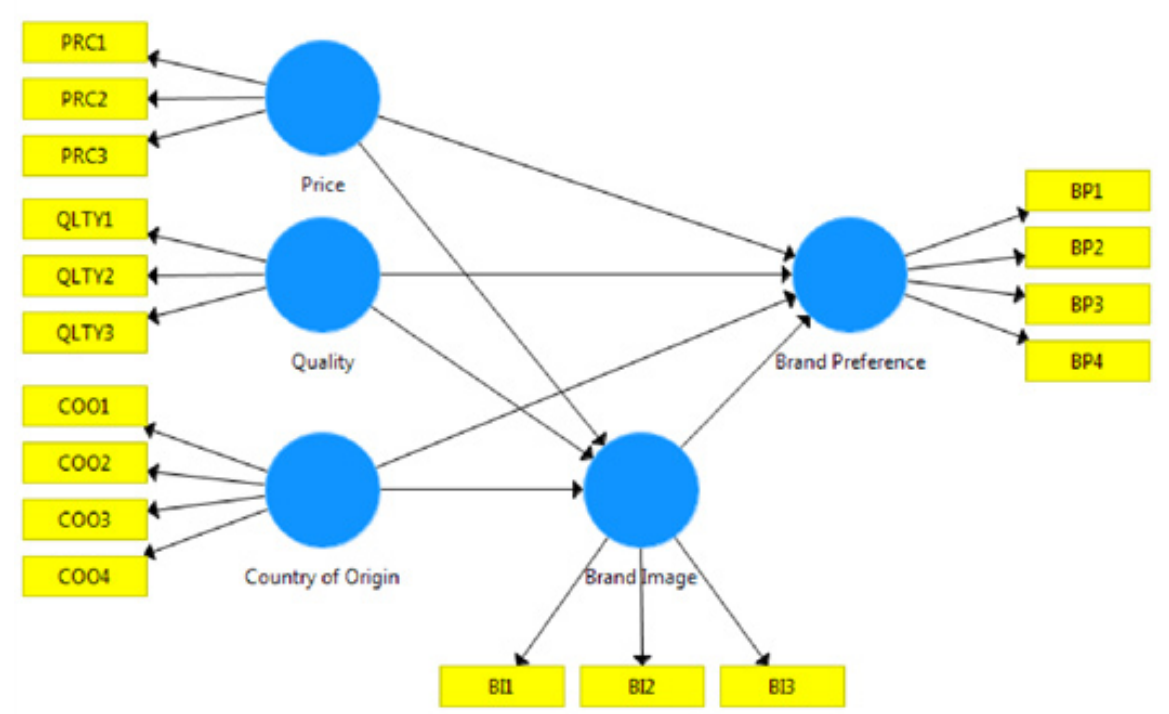

Figure 2. Initial model 


\section{RESULTS}

\section{Respondent Characteristics}

Respondent characteristics are commonly is used by marketers to determine market segmentation. The relationship between consumer brand preferences and market characteristics is an important key for marketers to create effective marketing strategies (Feng, 2007). Based on the descriptive analysis, Indonesian respondents (59\%) and Malaysian respondents (55\%) were mostly women. Based on the age range, the majority of Indonesian respondents $(82 \%)$ and Malaysian respondents (87\%) were between 18 and 25 years. Based on the monthly expenditure, the majority of Indonesian respondents (39\%) and Malaysian respondents (35\%) had expenses of USD (\$) 66.31-81.04. Based on the education level, the majority of Indonesian respondents (59\%) and Malaysian respondents $(67 \%)$ were at undergraduate level. Based on the different test on respondent's characteristic, there is a difference of education level in both groups of respondents ( $p$-value $<0.05$ ).

Perception of Handphone from China, America, South Korea, and Europe

Figure 3 shows the average value of Indonesian consumers' perception towards four handphones from various countries (China, South Korea, America, and Europe). There are 7 attributes assessed by respondents. The seven attributes are features quality, durability quality, performance quality, service quality, design, price, and country of origin.
Based on Figure 3, each handphone has their own advantages. ANOVA test results (Table 1) shows that there are differences in the average value of the four handphones based on their respective attributes. Chinese handphone brands have a very good price perception in the eyes of Indonesian consumers. The price attributes of Chinese handphones are superior to other handphones. Chinese handphones have lower value compared to other handphones, in terms of feature quality, performance quality, durable quality, service, design, and country of origin. Durable quality and service quality of Chinese handphones are considered less good. It indicates that the quality of Chinese handphones is still under the quality of American handphones, European handphones, and South Korean handphones. The perception of American handphones has a good value compared to other handphones. Indonesian consumers assess that American handphones have a very good quality, both in terms of design and quality. The most favored attribute of the American brand is the design. In addition to brands from America, handphones from South Korea are also superior in terms of design attributes. Indonesian consumers rate that the quality of South Korean handphones is pretty good. European handphones excel in durable quality. Indonesian consumer perceptions towards European handphones are also quite good. Based on the semantic differential scale results, the American handphones are the most superior, the second position is the South Korean handphones, and the third position is the European handphones while the brand from China has an advantage in terms of price.

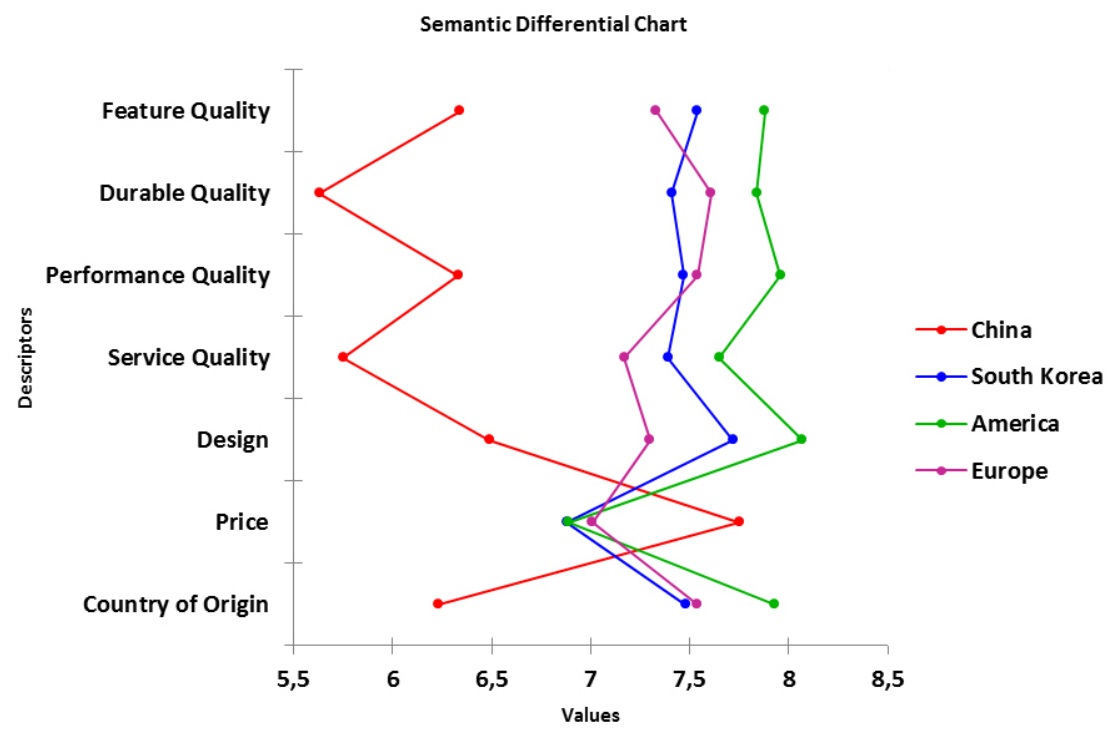

Figure 3. Semantic differential scale results on Indonesian Consumers 
Table 1. ANOVA test of headphone attributes on indonesian consumers

\begin{tabular}{|c|c|c|c|c|c|c|}
\hline & & Sum of Squares & $\mathrm{df}$ & Mean Square & $\mathrm{F}$ & Sig. \\
\hline \multirow{3}{*}{$\begin{array}{l}\text { Feature } \\
\text { Quality }\end{array}$} & Between Groups & 131.348 & 3 & 43.783 & 27.610 & .000 \\
\hline & Within Groups & 627.950 & 396 & 1.586 & & \\
\hline & Total & 759.297 & 399 & & & \\
\hline \multirow{3}{*}{$\begin{array}{l}\text { Durable } \\
\text { Quality }\end{array}$} & Between Groups & 306.268 & 3 & 102.089 & 62.899 & .000 \\
\hline & Within Groups & 642.730 & 396 & 1.623 & & \\
\hline & Total & 948.998 & 399 & & & \\
\hline \multirow{3}{*}{$\begin{array}{l}\text { Performance } \\
\text { Quality }\end{array}$} & Between Groups & 146.050 & 3 & 48.683 & 30.713 & .000 \\
\hline & Within Groups & 627.700 & 396 & 1.585 & & \\
\hline & Total & 773.750 & 399 & & & \\
\hline \multirow{3}{*}{$\begin{array}{l}\text { Service } \\
\text { Quality }\end{array}$} & Between Groups & 216.560 & 3 & 72.187 & 40.524 & .000 \\
\hline & Within Groups & 705.400 & 396 & 1.781 & & \\
\hline & Total & 921.960 & 399 & & & \\
\hline \multirow[t]{3}{*}{ Design } & Between Groups & 138.930 & 3 & 46.310 & 28.447 & .000 \\
\hline & Within Groups & 644.660 & 396 & 1.628 & & \\
\hline & Total & 783.590 & 399 & & & \\
\hline \multirow[t]{3}{*}{ Price } & Between Groups & 51.888 & 3 & 17.296 & 8.212 & .000 \\
\hline & Within Groups & 834.090 & 396 & 2.106 & & \\
\hline & Total & 885.978 & 399 & & & \\
\hline \multirow{3}{*}{$\begin{array}{l}\text { Country of } \\
\text { origin }\end{array}$} & Between Groups & 163.170 & 3 & 54.390 & 37.918 & .000 \\
\hline & Within Groups & 568.020 & 396 & 1.434 & & \\
\hline & Total & 731.190 & 399 & & & \\
\hline
\end{tabular}

Figure 4 shows the average value of Malaysian consumers' perceptions toward four handphones from different countries (China, South Korea, America, and Europe). There are 7 attributes assessed by respondents. The seven attributes are features quality, durable quality, performance quality, service quality, design, price, and country of origin of the brand.

Figure 4 shows the average rating of all four handphones based on each attribute. ANOVA analysis (Table 2) shows that there are significant differences between the four handphones based on each attribute. The brand of handphone from America has superior value in every attribute, except on the attribute of price perception, while handphones from China have a good price perception in the eyes of Malaysian consumers. Handphones from South Korea and Europe also have advantages in terms of quality and design, but the value is still under the handphones from America. Based on demographic characteristics, Malaysian consumers are in the productive age range and most respondents own American handphones (30\%). This shows that Malaysian consumers are more concerned with the quality of performance and design. Research conducted by Yee et al. (2013) also states that Malaysian consumers of $Y$ generation make quality attributes the first consideration when purchasing a smartphone.

\section{Comparing Perception of Indonesian Consumers and Malaysian Consumers based on Seven Attributes of Four Handphones}

In general, Indonesian consumers and Malaysian consumers have different perceptions on all four handphones based on their respective attributes. Based on handphone ownership, Indonesian consumers prefer handphone from South Korea (36\%) and China (13\%). Handphones from South Korea excel in design while the Chinese handphone excels in term of price attributes. In addition, according to Figure 3 the perception of handphone from America is considered superior to handphone brands from other countries. However, the American brand is considered to have an unfavorable price perception in the eyes of Indonesian consumers. 


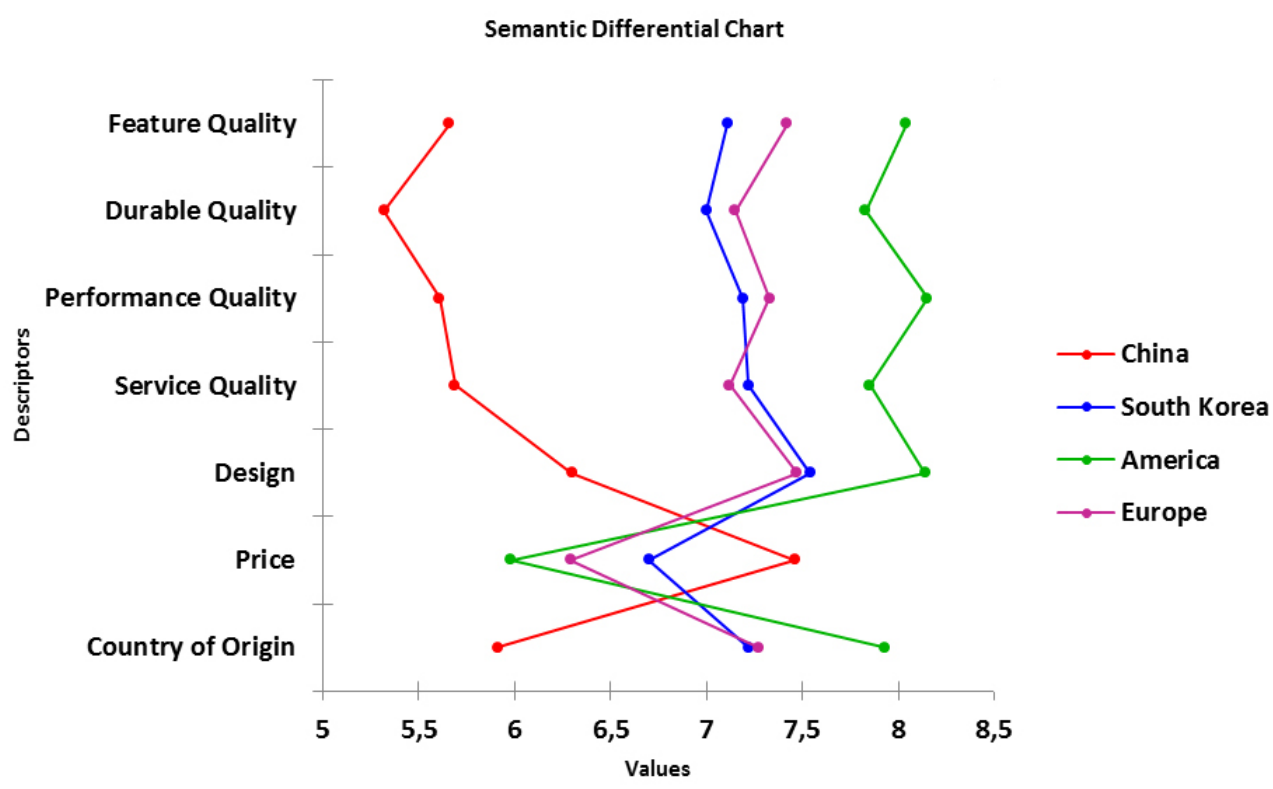

Figure 4. Semantic differential scale results on Malaysian Consumers

Table 2. ANOVA Test of headphone attributes on Malaysian Consumers

\begin{tabular}{|c|c|c|c|c|c|c|}
\hline & & Sum of Squares & df & Mean Square & $\mathrm{F}$ & Sig. \\
\hline \multirow{3}{*}{$\begin{array}{l}\text { Feature } \\
\text { Quality }\end{array}$} & Between Groups & 305.247 & 3 & 101.749 & 40.518 & .000 \\
\hline & Within Groups & 994.430 & 396 & 2.511 & & \\
\hline & Total & 1299.678 & 399 & & & \\
\hline \multirow{3}{*}{$\begin{array}{l}\text { Durable } \\
\text { Quality }\end{array}$} & Between Groups & 341.130 & 3 & 113.710 & 51.250 & .000 \\
\hline & Within Groups & 878.620 & 396 & 2.219 & & \\
\hline & Total & 1219.750 & 399 & & & \\
\hline \multirow{3}{*}{$\begin{array}{l}\text { Performance } \\
\text { Quality }\end{array}$} & Between Groups & 338.000 & 3 & 112.667 & 47.361 & .000 \\
\hline & Within Groups & 942.040 & 396 & 2.379 & & \\
\hline & Total & 1280.040 & 399 & & & \\
\hline \multirow{3}{*}{$\begin{array}{l}\text { Service } \\
\text { Quality }\end{array}$} & Between Groups & 308.347 & 3 & 102.782 & 43.388 & .000 \\
\hline & Within Groups & 938.090 & 396 & 2.369 & & \\
\hline & Total & 1246.438 & 399 & & & \\
\hline \multirow[t]{3}{*}{ Design } & Between Groups & 177.648 & 3 & 59.216 & 23.525 & .000 \\
\hline & Within Groups & 996.790 & 396 & 2.517 & & \\
\hline & Total & 1174.438 & 399 & & & \\
\hline \multirow[t]{3}{*}{ Price } & Between Groups & 122.987 & 3 & 40.996 & 13.067 & .000 \\
\hline & Within Groups & 1242.390 & 396 & 3.137 & & \\
\hline & Total & 1365.378 & 399 & & & \\
\hline \multirow{3}{*}{$\begin{array}{l}\text { Country of } \\
\text { origin }\end{array}$} & Between Groups & 214.707 & 3 & 71.569 & 31.228 & .000 \\
\hline & Within Groups & 907.570 & 396 & 2.292 & & \\
\hline & Total & 1122.278 & 399 & & & \\
\hline
\end{tabular}

The brand of handphone from Europe is considered to have good durability. Indonesian consumers prefer handphones that have good design and quality features. In contrast with Malaysian consumers, majority respondents use American handphone namely Apple $(30 \%)$. The second position is Samsung (23\%), while the third position is Oppo (11\%). The level of handphone ownership from China has been increasing in both countries. There are various brands of handphones from China owned by Indonesian consumers and Malaysian consumers. This shows that preference of Chinese brand is increasing. 
Based on ANOVA and semantic differential scale results, Indonesian consumers and Malaysian consumers have different perceptions of the four handphones (China, South Korea, America and Europe) based on their respective attributes. According to Indonesian consumers, American and South Korean handphones have a good perception in terms of design, performance quality, and features quality. Chinese handphones also have good quality in term of features. In addition to feature quality, affordable price is one of the hallmarks of Chinese handphones. Malaysian consumers consider that handphones from America excel in terms of quality performance and design. The perception of handphones from Korea is also considered to have a good design. Malaysian consumers have the same perception with Indonesian consumers on Chinese handphone, that is, Chinese phones are considered to have affordable prices and good design. Perceptions of handphones from Europe is considered to have good durability. If associated with the frequency of ownership and the semantic differential scale analysis, there are some considerations in preference for a handphone. In Indonesian consumers, it indicates that the first consideration in choosing a handphone is more concern with the design attribute, and the second consideration is the performance quality and features quality. As for Malaysian consumers, the first consideration in choosing a handphone is performance quality, and the second consideration is design, and feature quality. This study is in line with the research conducted Yee et al. (2013) which argue that Malaysian consumers prefer the design of a handphone. Overall, Indonesian and Malaysian consumers rate the American handphones to be superior in every attribute, except price. In contrast, Chinese handphone are considered superior in terms of affordable prices.

\section{Product Attribute and Brand Image Affecting Brand Preference}

The influence of product attributes and brand images is tested using SEM-PLS. There are five variables tested in the model. These five variables are brand image and product attributes including price, quality and country of origin. There are two assessments in the SEM -PLS method, which is an outer model assessment and an inner model assessment. The initial stage in the evaluation of SEM-PLS model is to eliminate the loading factor that has below standard value $(<0.7)$.

\section{Reflective Outer Model Assessment}

A reflective outer model assessment consists of three criteria. The three criteria are composite reliability ( $\rho c)$, cronbach's alpha, and average variance extract (AVE) (Table 3).Composite reliability ( $\rho$ c). $\rho c>0.7$ Values above 0.7 indicate that internal stability and consistency of latent variable indicators are excellent. In Malaysian model, all of the latent variables have composite reliability value above $>0.7$ while in Indonesian model there is composite reliability value below standard value $(<0.7)$.Validity test refers to a test which is consistent and valid. Validity is also a standard measure that shows accuracy. This measurement is illustrated by the Average Variance Extracted (AVE) value. The standard AVE value is above 0.5 . The overall latent variables in both models (Indonesia and Malaysia) in this study had an AVE score above 0.5. Based on the standard of AVE value, it indicates that this research is very consistent and precise in measuring instrument. The last criteria is Cronbach alpha. A good model has value above 0.7 It indicates that its contracts are reliable. In Malaysian model, construct value has fulfilled the standard value. In contrast with Indonesian model, the construct value does not meet the crobanch alpha standard value. Generally, reflective the outer model assessment on both models have fulfilled the standard value, which indicates that the construct value is reliable and consistent.

\section{Inner Model Assessment}

An inner model assessment is used to analyze the relationship of latent variables in model. The inner model assessment includes $\mathrm{R}^{2}$ of endogen latent variable and path coefficient. Assessment of $\mathrm{R}^{2}$ shows how many endogenous variables are capable of being explained by exogenous variables. Category of $\mathrm{R}^{2}$ value based on Chin (1998) in Ratono (2010) is substantial (0.67), moderate (0.33), and weak (0.19). Indonesian model is between moderate and substantial (0.459 and 0.551), while Malaysian model is between weak and moderate (0.170 and 0.333) (Table 4).

Based on bootstrap results, this study implies that there are different hypotheses on both models. Product attribute affects brand preference. Indonesian consumers are more concerned with country of origin to increase brand preference. In contrast, Malaysian consumers do not consider country of origin of handphone. In addition, product quality has influence on brand image and brand preference. Indonesian consumers and Malaysian 
consumers are more concerned with product quality. Quality of handphone reflects their brand image. This study is in line with the research conducted by Khan (2016). Khan (2016) states that quality is a symbol of a brand image. Price attribute does not affect brand image and brand preference. Indonesian consumers and Malaysian consumers do not consider price attribute when they see brand image of the product. This study indicates that price does not reflect brand image. In addition, low prices do not increase consumer's preference for a particular brand. Majority of Indonesian consumers and Malaysian consumers were young consumers. It indicates that young consumers are less sensitive to price. Khan (2016) also argue that young consumers are less sensitive to price when they increase their self-image.

\section{Managerial Implications}

The enhancement of import handphone indicates that telecommunication industry is highly competitive. There are various handphone brands that are offered by marketers. The local telecommunication industry should be able to develop its products and expand to global market. This study indicates that product attributes such as quality, country of origin, and price are being considered by consumers. In addition, demographic characteristics also affect brand preference.

Table 3. Reliability construct and model validity

\begin{tabular}{lcccccc}
\hline \multirow{2}{*}{ Latent variable } & \multicolumn{3}{c}{ Indonesia } & \multicolumn{3}{c}{ Malaysia } \\
\cline { 2 - 7 } & $\begin{array}{c}\text { Cronbach } \\
\text { alpha }\end{array}$ & $\begin{array}{c}\text { Composit } \\
\text { reliability }\end{array}$ & $\begin{array}{c}\text { Average Variance } \\
\text { Extracted (AVE) }\end{array}$ & $\begin{array}{c}\text { Cronbach } \\
\text { alpha }\end{array}$ & $\begin{array}{c}\text { Composit } \\
\text { reliability }\end{array}$ & $\begin{array}{c}\text { Average Variance } \\
\text { Extracted (AVE) }\end{array}$ \\
\hline Brand image & 0.671 & 0.820 & 0.603 & 0.800 & 0.883 & 0.716 \\
Country of origin & 0.608 & 0.836 & 0.718 & 0.703 & 0.867 & 0.766 \\
Price & 0.596 & 0.832 & 0.712 & 0.736 & 0.882 & 0.789 \\
Quality & 0.799 & 0.880 & 0.710 & 0.843 & 0.905 & 0.760 \\
Brand preference & 0.941 & 0.958 & 0.849 & 0.921 & 0.944 & 0.807 \\
\hline
\end{tabular}

Table 4. Bootstrap results

\begin{tabular}{lcccc}
\hline & \multicolumn{2}{c}{ Malaysia } & \multicolumn{2}{c}{ Indonesia } \\
\cline { 2 - 5 } & T Statistics & Hyphoteses & T Statistics & Hyphoteses \\
\hline Brand image $\rightarrow$ Brand preference & 1.628 & H4: Rejected & 0.511 & H4: Rejected \\
Country of origin $\rightarrow$ Brand image & $2.571^{*}$ & H3b: Accepted & $4.052^{* *}$ & H3b: Accepted \\
Country of origin $\rightarrow$ Brand preference & 1.189 & H3a: Rejected & $2.117^{*}$ & H3a: Accepted \\
Price $\rightarrow$ Brand image & 0.932 & H1b: Rejected & 1.271 & H1b: Rejected \\
Price $\rightarrow$ Brand preference & 0.971 & H1a: Rejected & 0.173 & H1a: Rejected \\
Quality $\rightarrow$ Brand image & $4.108^{* *}$ & H2b: Accepted & $5.215^{* *}$ & H2b: Accepted \\
Quality $\rightarrow$ Brand preference & $1.984^{*}$ & H2a: Accepted & $6.494 * *$ & H2a: Accepted \\
\hline
\end{tabular}

Note: T-statistic $>$ T-table of 1.96 at $5 \%$ of real level

American handphone brands and South Korean handphone brands have a good perception in Indonesian consumers and Malaysian consumers, especially in terms of quality and design. There is a little difference between Indonesian consumers and Malaysian consumers. Indonesian consumers are more concerned with design while Malaysian consumers are more concerned with performance quality. An attribute of handphone is a priority for Indonesian consumers and Malaysian consumers. In addition, consumers in both countries have a good price perception towards Chinese handphones.

Marketers should increase consumers' brand preference. There are several factors affecting brand preference, such as quality and country of origin. Based on statistic analysis, it implies that quality and country of origin affect brand preference. Indonesian consumers and Malaysian consumers see the country of origin as one of the factors reflecting the brand image. Indonesian consumers still consider that country of origin can increase brand preference of handphone. In contrast, Malaysian consumers do not consider country of origin as one of the factors affecting brand preference. Price is not a major consideration for Indonesian consumers and Malaysian consumers. An important element that affects brand preference is quality. Quality includes feature quality, performance quality, and design of handphone. Marketers should create new innovations on its product, such as offering the different feature quality, different performance quality, and unique design. 


\section{CONCLUSIONS AND RECOMMENDATIONS}

\section{Conclusions}

The conclusion that can be drawn from the results of this research, is a difference of perception between Indonesian consumers and Malaysian consumers. Indonesian consumers are more concerned with design and features quality while Malaysian consumers are more concerned with performance quality. Marketers must be able to provide superior features, design, and performance quality of handphone products in order to win the market. Product attributes are related to brand image of product. Product quality attributes affect brand image and brand preference. In addition to product quality, Indonesian and Malaysian consumers assume that country of origin reflects the brand image. Indonesian consumers see the country of origin as one of the factors that can increase brand preference. In contrast, Malaysian consumers do not see country of origin as a decisive factor in increasing brand preference.

\section{Recommendations}

For future research, random sampling can be used so that samples can be generalized. Future research should be able to enhance the total sample size to represent the population. In addition, future research should be able to examine a wide range of factors affecting brand preference. There are several factors that affect brand preference, but they are not examined in this research, such as customer satisfaction and brand familiarity. Further research can examine more deeply factors related to the perception of handphone and brand preference.

\section{REFERENCES}

Alamro A, Rowley J. 2011. Antecedents of brand preference for mobile telecommunications services. Journal of Product \& Brand Management 20(6): 475-486, https://doi. org/10.1108/10610421111166621.

Andhika G, Yuliati L, Kirbrandoko. 2016. Factors affecting brand choice of the consumers on sports drinks. Indonesian Journal of Business and Entrepreneurship (2)3:208-218. http:// dx.doi.org/10.17358/ijbe.2.3.208.
Bass FM, Talarzyk W. 1972. An attitude model for the study of brand preference. Journal of Marketing Research 9(1): 93-96. https://doi. org/10.2307/3149618.

Duarte P, Raposo M. 2010. A PLS Model to Study Brand Preference: an Application to The Market. Berlin: Springer Handbooks of Computational Statistics.

Ebrahim R, Ghoneim A, Irani Z, Fan Y. 2016. A brand preference and repurchase intention model: the role of consumer experience. Journal of Marketing Management 32(13-14): 1230-1259. https://doi.org/10.1080/0267257X.2016.115032 2.

Essoussi LH, Merunka D, Bartikowski B. 2011. Brand origin and country of manufacture influences on brand equity and the moderating role of brand typicality. Journal of Business Research 64(9): 973-978. https://doi.org/10.1016/j. jbusres.2010.11.020.

Feng LC. 2007. Segmenting customer brand preference; demographic and psychographic. Journal of Product and Brand Management 11(4):249-268. https://doi.org/10.1108/10610420210435443.

Godey B, Pederzoli D, Singh R, Oh H. 2012. Brand and country of origin effect on consumer decision to purchase luxury products. Journal of Business Research 65(10):1461-1470. https:// doi.org/10.1016/j.jbusres.2011.10.012.

Hellier P, Geur SG, Carr R, Rickard G. 2003. Customer repurchase intention: a general sequence model. European Journal of Marketing 37(11): 17621800, doi: 10.1108/03090560310495456.

IDC. 2017. International data corporation. http://www. idc.com/getdoc.jsp?containerId=prAP42312617 $\& j=21081986 \&$ e [July 27, 2017].

Khan M. 2016. Factors of consumer choice of smartphone: a study on brand image and brand featires. Market Forces 11(2):1-10.

Kim S, Choi Y, Kim K, Liu H. 2015. Country of origin and brand image influences on perceptions of online game. Journal of Consumer Behavior 14(6):389-398. https://doi.org/10.1002/cb.1554.

Kotler P. 2002. Manajemen Pemasaran. Jakarta: Prehalindo.

Laforet S, Chen J. 2012. Chinese and british consumers evaluation of chinese and international brands and factors affecting their choice. Journal of World Business 47(1): 54-63. https://doi. org/10.1016/j.jwb.2010.10.020. 
Lee J, Nguyen M. 2017. Product attribute and preference for foreign brands among vietnamese consumers. Journal of Retailing and Consumer Service 35:76-83. https://doi.org/10.1016/j. jretconser.2016.12.001.

Nadia N, Rashid W. 2016. The influence of country of origin on consumer purchase intention: the $\mathrm{s}$ brand from China. Procedia Economics and Finance 37:343-349. https://doi.org/10.1016/ S2212-5671(16)30135-6.

Renganathan R, anand V, Srinivasakunar V. 2016. A study on consumer brand preference with reference to DTH in Rural Area. Indian Journal of Science and Technology 9(27). https://doi. org/10.17485/ijst/2016/v9i27/97621.

Roscoe J. 1975. Fundamental Research Statistics for the Behavioral Sciences. New York: Holt, Rinehart, and Winston.

Roseli N, Azhar S, Samsudin S, Johari F, Ismail W. 2016. An Analysis on the preferences of smartphone that affects consumers buying decision in selected higher education institution in Malaysia. International Academic Research Journal of Business and Technology 2(2): 9195.

Saakjarvi M, Samiee S. 2011. Relationships among brand identity, brand image and brand preference. Journal of Interactive Marketing 25(3):169-177. https://doi.org/10.1016/j.intmar.2011.04.002.

Salkind N. 2010. Encyclopedia of Research Design. London UK: SAGE Publication. https://doi. org/10.4135/9781412961288.

Schultz D, Block M, Viswanathan V. 2014. Brand preference being challenged. Journal of Brand Management 21(5): 408-428. https://doi. org/10.1057/bm.2014.5.

Top brand index. 2017. Top brand index. http://www. topbrand-award.com/top-brand-survey/surveyresult/top_brand_index_2017_fase_1 [July 27, 2017].

Yee K, Siew H, Fah B. 2013. Factors affecting smartphone purchase decision among Malaysian generation Y. International Journal of Asian Social Science 3(12): 2426-2440. 